\title{
Coral disease following massive bleaching in 2005 causes $60 \%$ decline in coral cover on reefs in the US Virgin Islands
}

\author{
J. Miller $\cdot$ E. Muller $\cdot$ C. Rogers $\cdot$ R. Waara $\cdot$ \\ A. Atkinson - K. R. T. Whelan · M. Patterson • \\ B. Witcher
}

Received: 18 September 2008/Accepted: 19 June 2009/Published online: 28 July 2009

(C) The Author(s) 2009. This article is published with open access at Springerlink.com

\begin{abstract}
In the northeast Caribbean, doldrum-like conditions combined with elevated water temperatures in the summer/fall 2005 created the most severe coral bleaching event ever documented within this region. Video monitoring of 100 randomly chosen, permanent transects at five study sites in the US Virgin Islands revealed over $90 \%$ of the scleractinian coral cover showed signs of thermal stress by paling or becoming completely white. Lower water temperatures in October allowed some re-coloring of corals; however, a subsequent unprecedented regional outbreak of coral disease affected all sites. Five known diseases or syndromes were recorded; however, most lesions showed signs similar to white plague. Nineteen scleractinian species were affected by disease, with $>90 \%$ of the disease-induced lesions occurring on the genus
\end{abstract}

Communicated by Biology Editor Dr. Clay Cook

\section{J. Miller $(\bowtie)$}

National Park Service, South Florida/Caribbean Inventory and Monitoring Network, 1300 Cruz Bay Creek, St John, VI 00830, USA

e-mail: William_J_Miller@nps.gov

E. Muller

Department of Biological Sciences, Florida Institute of

Technology, 150 W. University Blvd., Melbourne, FL 32901,

USA

C. Rogers

US Geological Survey, 1300 Cruz Bay Creek, St. John, VI 00830, USA

R. Waara - A. Atkinson - K. R. T. Whelan · M. Patterson · B. Witcher

National Park Service, South Florida/Caribbean Inventory and Monitoring Network, 18001 Old Cutler Road, Suite 419, Palmetto Bay, FL 33157, USA
Montastraea. The disease outbreak peaked several months after the onset of bleaching at all sites but did not occur at the same time. The mean number of disease-induced lesions increased 51-fold and the mean area of diseaseassociated mortality increased 13-fold when compared with pre-bleaching disease levels. In the 12 months following the onset of bleaching, coral cover declined at all sites (average loss: $51.5 \%$, range: $42.4-61.8 \%$ ) reducing the five-site average from $21.4 \%$ before bleaching to $10.3 \%$ with most mortality caused by white plague disease, not bleaching. Continued losses through October 2007 reduced the average coral cover of the five sites to $8.3 \%$ (average 2-year loss: $61.1 \%$, range: $53.0-79.3 \%$ ). Mean cover by M. annularis (complex) decreased 51\%, Colpophyllia natans $78 \%$ and Agaricia agaricites $87 \%$. Isolated disease outbreaks have been documented before in the Virgin Islands, but never as widespread or devastating as the one that occurred after the 2005 Caribbean coral-bleaching event. This study provides insight into the effects of continued seawater warming and subsequent coral bleaching events in the Caribbean and highlights the need to understand links between coral bleaching and disease.

Keywords Coral bleaching - Coral disease . Coral monitoring $\cdot$ Caribbean reefs

\section{Introduction}

Coral-bleaching events followed by disease outbreaks are a recently described phenomenon (Selig et al. 2006; Bruno et al. 2007; Whelan et al. 2007; Muller et al. 2008). Independently, coral bleaching and coral disease have become substantial threats to coral reefs over the last several decades. Only recently, however, have the two 
stressors been suggested to have a connection. The suggested link between coral bleaching and disease is anomalously high-water temperatures. Many factors can cause coral bleaching, though changes in temperature and ultraviolet radiation have received the most attention (Brown 1997). Typically, massive bleaching events in the past have been associated with higher than average water temperatures $\left(\sim 1^{\circ} \mathrm{C}\right)$ in the summer months, when corals are already close to their temperature threshold. Whether high temperatures affect diseases and bleaching independently, or indirectly through a series of connected biological responses (e.g., coral-host susceptibility), is unknown.

The number and severity of coral-bleaching events have increased substantially since the early 1980s (Williams and Bunkley-Williams 1990; Hoegh-Guldberg 1999). While bleaching events such as the one in 1998 caused extensive mortality worldwide, coral bleaching in the Atlantic has until recently caused either isolated or relatively low levels of coral mortality. During the 1997/1998 bleaching event, coral mortality in the Atlantic was fairly minor compared with mortality levels in the Indian and Pacific Oceans (Goreau et al. 2000). Rogers and Miller (2001) reported less than $50 \%$ of coral cover bleached from two sites in St. John at this time with little subsequent mortality. The only major loss of coral reported in the Caribbean region from the bleaching in 1997/1998 was along the central shelf lagoon of the Belizean barrier reef where $\sim 100 \%$ of the Agaricia tenuifolia died (Aronson et al. 2002). In 2003, Ballantine et al. (2008) reported $<1.0 \%$ scleractinian mortality from a coral-bleaching event in Puerto Rico.

Coral disease was first documented in 1965 (Squires 1965), but, similar to bleaching, was not considered a serious threat to coral reefs until recently. The number of described coral diseases and the number of documented cases have increased exponentially since the first description (Harvell et al. 2004; Lafferty et al. 2004). Coral disease is now considered one of the greatest threats to coral reefs and has been a significant cause of reef degradation throughout the world (Rosenberg and Loya 2004). The Caribbean has been labeled a 'hot-spot' for disease with approximately $76 \%$ of all coral diseases described worldwide being found within this relatively small basin (Weil 2004). Historically, disease has taken a toll on Caribbean coral reefs. In the late 1970s, white band disease caused the precipitous decline of two major, reef-building coral species, Acropora palmata and A. cervicornis, the first coral species listed as threatened under the Endangered Species Act, 71 Federal Register 26852 (Federal Register 2006). Recently, white plague and Caribbean yellow band diseases are considered the major disease threats within the Caribbean (Miller et al. 2003; Weil et al. 2006; Ballantine et al. 2008; Rogers et al. 2008).

\section{Temperature/disease connection}

High-water temperatures can influence coral disease by either increasing pathogenic abundance or virulence (Rosenberg and Ben-Haim 2002), or by increasing coralhost susceptibility (Lesser et al. 2007; Ainsworth et al. 2008). Several coral pathogens have displayed optimal growth at relatively high ambient temperatures (30$35^{\circ} \mathrm{C}$ ). A pathogen identified for white plague type II, Aurantimonas coralicida, and a pathogen documented to cause white pox disease, Serratia marcescens, have optimal growth ranges between 30 and $35^{\circ} \mathrm{C}$ (Patterson et al. 2002; Remily and Richardson 2006). Higher abundance of potential pathogens in the environment, or within the coral host, could increase the potential for disease infection. High-water temperatures may promote the growth and reproduction of microbial pathogens. One species of coral, Oculina patagonica, bleached from the temperature-sensitive bacterium Vibrio shiloii (Ben-Haim and Rosenberg 2002; the name $V$. shiloii is now renamed to V. shilonii (List Editor 2001)). Follow-up studies, however, indicated $O$. patagonica no longer bleached in the presence of the $V$. shilonii. Therefore, the corals either developed a resistance to the bacteria (Reshef et al. 2006), bleaching was always a result of changing environmental conditions and not a result of bacterial infection (Ainsworth et al. 2008) or the virulence of the pathogen was reduced.

Elevated water temperatures could physiologically stress the coral holobiont and lead to bleaching, therefore increasing the coral's susceptibility to disease. A combination of bleaching and disease in 1998 caused extensive mortality of the octocoral, Briareum asbestinum, in the Florida Keys (Harvell et al. 2001). This short-lived epizootic occurred within 10 weeks of the bleaching event. Additionally, a study by Jones et al. (2004) documented a coral epizootic that coincided with a bleaching event at Magnetic Island (Great Barrier Reef) in which coral mortality was attributed to disease. Bruno et al. (2007) found a significant relationship between the frequencies of warm water temperature anomalies and white syndrome in the Great Barrier Reef but only on reefs with $>50 \%$ coral cover. Furthermore, during the 2005 Caribbean coralbleaching event, on a section of Tektite Reef USVI, Whelan et al. (2007) documented that mortality in Porites porites was from bleaching; however, Colpophyllia natans bleached before dying from white plague. At another US Virgin Islands site, bleached Acropora palmata colonies lost more tissue from disease than A. palmata colonies that did not bleach (Muller et al. 2008). Greater mortality on the more compromised corals suggests disease severity was influenced by coral-host stress and susceptibility. 
During the summer/fall of 2005, anomalously warm water temperatures (Whelan et al. 2007) and doldrum-like conditions in the NE Caribbean coincided with massive coral bleaching (Wilkinson and Souter 2008). The 2005 Atlantic hurricane season was the most active ever recorded with 28 tropical storms including 15 hurricanes. However, the NE Caribbean was largely unaffected as no storm or hurricane passed within $400 \mathrm{~km}$ of this area. Coral bleaching as referred to in this paper is defined as paling or whitening of a coral from the loss of zooxanthellae or zooxanthellar pigments. While some scientists include bleaching as a disease (e.g., Rosenberg and Ben-Haim 2002), the present study differentiated coral bleaching from coral disease. Bleached corals retained living tissue with an absence or reduction of zooxanthellae while disease was a measure of coral mortality (i.e., loss of tissue) when signs consistent with previously described coral diseases were observed. This study documented the extent and severity of coral bleaching on five reef sites around St. John and St. Croix, US Virgin Islands, and explored the connection between coral bleaching and coral disease during massive bleaching in 2005 and subsequent disease outbreak.

\section{Methods}

\section{Study sites}

St. John and St. Croix, two of the US Virgin Islands (USVI), are located in the northeast Caribbean at $18^{\circ} \mathrm{N}$, $64^{\circ} \mathrm{W}$. Beginning in 1999, long-term monitoring sites were established on complex, well-developed reefs around St. John and St. Croix and monitored annually to estimate coral cover and detect changes in benthic communities over time. Virgin Islands National Park (VINP), established in 1956 and expanded in 1962, includes 56\% of the island of St. John with over 7,000 terrestrial acres and 5,650 acres of submerged lands. Annual monitoring began at three sites inside VINP: Mennebeck (in 2000), Haulover (2003), and Tektite Reefs (2005) and one site outside the park, Newfound Reef (1999). A fifth site, the South Fore Reef, located within Buck Island Reef National Monument (BIRNM) near St. Croix (Fig. 1), was established in 2002. All sites are forereef zones which ranged in area from 12,495 to $40,753 \mathrm{~m}^{2}$ with depths ranging from 3.7 to $10.4 \mathrm{~m}$ at Haulover Reef (shallow site) to 7.6-18.9 m at Tektite Reef (deep site). Newfound, Mennebeck, Haulover and South Fore Reef are windward-facing reefs while Tektite Reef is in a relatively protected bay. All reefs are in undeveloped watersheds, except Haulover Bay, which is bisected by the VINP boundary, with roads and homes constructed on the east (non-park) side of the watershed.
Data collection

Benthic cover was monitored using the random sample selection and video-monitoring protocols developed by the US Geological Survey (USGS) and National Park Service (Rogers et al. 2002). At each study site, the site boundaries were mapped using a diver-based SONAR mapping system (Aqua-Map). Within these boundaries, the total sample $(10 \mathrm{~m}$ transect) population was identified (given $10 \mathrm{~m} \times 10 \mathrm{~m}$ spacing) from which 20 transects (per study site) were randomly selected. The transect orientation was along a consistent compass heading per site designed to approximate the depth contours of the site. Transects were "permanent", relocated using the SONAR system and laminated photographs, and re-sampled each monitoring period. The sample design met the criteria for independent random sampling, allowing data collected to be extrapolated to the entire study site (Lewis 2004). Each transect was filmed along a fiberglass-measuring tape with a digital video camera pointed down, $40 \mathrm{~cm}$ above the substrate. Equipment that was in contact with the coral, such as fiberglass tapes used to define the transects, was used once then un-spooled and rinsed in a $10 \%$ bleach-freshwater solution before the next field use to minimize cross-contamination. Percent cover by selected benthic categories was determined in the laboratory. Using Microsoft Excel and Adobe Photoshop, 25-30 adjacent, non-overlapping images were captured from the video of each transect and 10 points were randomly applied to each captured image. The benthic feature under each random point was identified to the greatest taxonomic resolution (species or functional group) and entered into a Microsoft Access database (see Rogers et al. 2002 for protocol details). When a bleached scleractinian coral was found under the sample point, the bleaching severity for that point was defined as white or pale (e.g., Edmunds et al. 2003).

Coral diseases were quantified within $1 \mathrm{~m}$ on either side of each $10 \mathrm{~m}$ transect (total area $=20 \mathrm{~m}^{2} /$ transect; $400 \mathrm{~m}^{2} /$ site). Disease type, coral species affected, and area of mortality (length $\times$ maximum perpendicular width of lesion) were recorded. Disease-induced mortality was defined as white, recently exposed and uncolonized coral skeleton. Mortality from disease appeared as lesions with distinct borders separating living tissue (with or without pigment) from completely exposed, bare skeleton. Mortality from bleaching appeared as the degeneration of tissue with no visible pigmentation, simultaneously followed by the colonization of filamentous algae on the coral skeleton. Each lesion was photographed using a SONY T-33 digital camera. Dead coral colonized with turf algae was not quantified as "disease mortality" because the cause of tissue loss was not observed during the sampling survey. Colonization of lesions by turf algae occurred within days 
Fig. 1 Map of study locations from a St. John and b St. Croix
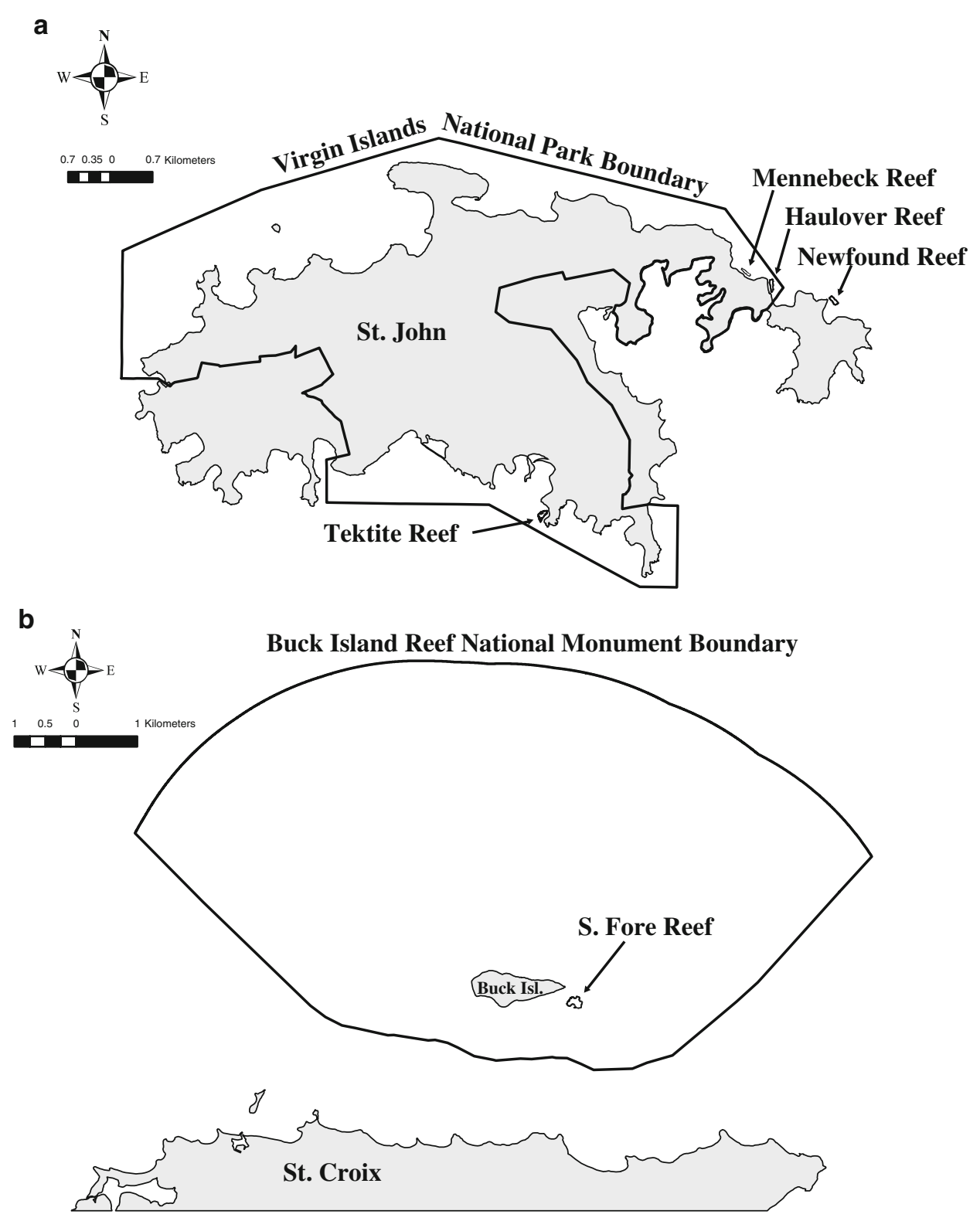

to weeks thus the areas of disease-induced mortality were never measured more than once, although some may have been expansions of previous lesions.

Each site, except Tektite Reef, was sampled annually before bleaching began in 2005. Three sites (Haulover, Newfound, and South Fore Reef) were surveyed in 2005 before bleaching was observed (January-March 2005 and referred to as 'initial' surveys) and are referred to as 'reference sites' hereafter. Sampling frequency increased after bleaching was observed in 2005, although the frequency varied among sites. Tektite Reef was sampled bi-monthly from September 2005 to September 2006, Haulover and Mennebeck Reefs were sampled approximately quarterly from October 2005 to July 2006, Newfound Reef was sampled November 2005, March 2006 and July 2006, and the South Fore Reef was sampled November 2005 and March 2006. All sites were sampled once in 2007.

Seawater temperatures at reef depth were recorded at $2 \mathrm{~h}$ intervals using data loggers (HOBO or Ryan Industries Temp-Mentors) positioned within two study reefs (Newfound and Haulover) and a third logger near Tektite Reef (at Yawzi Reef, $500 \mathrm{~m}$ west of Tektite). However, data are not available for every site each month. The median number of active sites in any given month from 1988 to 2007 was two and data gaps occurred from May 1988 to February 1990 and from March 1999 to August 2000. Ryan-brand loggers were sent for calibration annually, and all sensors were calibrated in-factory (documentation provided). A monthly mean was calculated per site and averaged to create a Virgin Islands monthly mean. 
Statistics

To determine if temperatures in 2005 were higher than 'normal' water temperatures, the average monthly water temperatures in 2005 were compared with historical average water temperatures from St. John (data collected from 1988 to 2004 from Newfound Reef, Haulover Reef, and Yawzi Reef) using a one-tailed $t$-test. Benthic cover data were evaluated for normality and homogeneity of variance by visual inspection of residuals and by conducting a regression analysis on the absolute value of the residuals with predicted values. If a positive trend in the residuals were detected, a square root $(x+1)$ transformation was performed, and the residuals were then tested for normality using an Anderson-Darling test (SAS ver. 9.1).

Changes in percent coral cover were analyzed separately for each site using a repeated measures analysis in which transect was treated as a subject factor and sampling date was treated as the repeated measure. Contrast analyses were used to test (a) whether a trend in coral cover was occurring in the pre-bleaching data only, and (b) whether there was a significant difference between the pre-bleaching and post-bleaching data. For the purposes of analysis, sampling periods before August 1, 2005 were labeled as "pre-bleaching" and sampling periods after January 1, 2006 were labeled as "postbleaching". The exception was the September 26, 2005 sampling date at the Tektite Reef that was also labeled "prebleaching" as previous data were not available. A TukeyKramer mean separation test was performed to establish differences in mean coral cover during different sample events within each site. A Type 1 error of 0.05 was used to determine the statistical significance of results.

Correlations between coral disease (number of lesions and area of disease-induced mortality) and temperature, and then between coral disease and coral cover were analyzed using Spearman Rank Correlation. Site averages were pooled to compare disease with temperature, and disease with coral cover.

The percent cover for individual coral species, except Montastraea annularis (complex, which includes M. franksi, M. faveolata, and M. annularis), was very low, and all species were not present in each transect. Therefore, to test whether a species-specific decrease occurred, instead of using individual transects, site averages were used and data from the five sites were combined. Each site was considered a replicate and site averages for each pre-bleaching and post-bleaching period were calculated. A paired $t$-test was conducted with sites as replicates using the prebleaching and post-bleaching averages from all five sites. Data were transformed using a square root $(x+1)$ transformation in keeping with the analysis of overall coral cover. Normality of the differences was tested using an AndersonDarling test (SAS 9.2. UNIVARIATE procedure).

\section{Results}

Pre-bleaching coral cover trends

The transects at four of the five study sites were monitored for 2-6 years prior to the bleaching event. Annual monitoring showed two sites increased in coral cover $(P<0.02)$ prior to August 2005; Mennebeck Reef increased from $23.0 \%( \pm 3.4)$ in 2000 to $26.7 \%( \pm 3.8)$ in 2004 and S. Fore Reef increased from $17.2 \%( \pm 1.9)$ in 2002 to $19.6 \%( \pm 1.6)$ in February 2005 (values are mean \pm standard error unless otherwise stated). Coral cover at Newfound Reef decreased significantly $(P=0.0002)$ from $18.0 \%( \pm 1.9)$ in 1999 to $13.3 \%( \pm 1.6)$ in March 2005 with the drop primarily occurring between 1999 and 2000 and showed no change thereafter. Haulover Reef showed no change in coral cover [mean $=22.5 \%( \pm 2.6)]$ from 2003 through January 2005.

\section{Bleaching}

Reef-depth water temperatures were higher than the historical average (1988-2004 monthly average) for St. John from April to September 2005, and the difference was statistically significant $(P<0.05)$ in April, June, August, and September 2005 (Fig. 2; Table 1). Bleaching of isolated scleractinian corals was first observed in July, when water temperatures averaged $29.2^{\circ} \mathrm{C}$. Coral bleaching became more severe as temperatures continued to be $0.7-0.9^{\circ} \mathrm{C}$ higher than historical averages until September. The maximum average monthly temperature, $30.2^{\circ} \mathrm{C}$, occurred in September 2005 which was $1.2^{\circ} \mathrm{C}$ warmer than the historical average. The 'peak' in coral bleaching (defined as the highest percent coral cover pale or white) occurred between September and November 2005 with $>90 \%$ of the coral cover at each study site displaying some sign of thermal stress, and the lowest maximum bleaching detected for any individual transect was $74 \%$. During this period, $>40 \%$ of the coral cover at each site was completely white. Water temperatures returned to near-normal in October 2005; however, bleaching continued at all sites, and $56 \%$ of the coral cover remained bleached or pale during the coldest period (January-April) in 2006. The four reefs sampled in July 2006 had an average of $34.6 \%$ coral cover still discolored; however, no coral cover was completely white at that time. Complete re-coloration (i.e., bleaching recovery) had still not occurred by the last sampling survey (Mennebeck Reef, October 2007). Overall, the onset of recovery from bleaching occurred soon after temperatures dropped (October 2005); however, complete colony re-coloration was slow and incomplete. The five reefs sampled in 2007 were still not homogenous in color when compared with the reefs in years before the 2005 Caribbean coral-bleaching event. 
Table 1 Results from individual $t$-tests comparing water temperatures in 2005-2007 to historical water temperatures of St. John, US Virgin Islands (NS: $P>0.05)$

\begin{tabular}{|c|c|c|c|c|c|c|c|c|c|c|}
\hline \multirow[t]{2}{*}{ Month } & \multicolumn{2}{|c|}{ Historical: 1988-2004 } & \multicolumn{4}{|l|}{2005} & \multicolumn{2}{|l|}{2006} & \multicolumn{2}{|l|}{2007} \\
\hline & $\begin{array}{l}\text { Monthly } \\
\text { average }\left({ }^{\circ} \mathrm{C}\right)\end{array}$ & SD & $\begin{array}{l}\text { Monthly } \\
\text { average }\left({ }^{\circ} \mathrm{C}\right)\end{array}$ & $t$-value & $d f$ & $P$ value & $\begin{array}{l}\text { Monthly } \\
\text { average }\left({ }^{\circ} \mathrm{C}\right)\end{array}$ & $P$ value & $\begin{array}{l}\text { Monthly } \\
\text { average }\left({ }^{\circ} \mathrm{C}\right)\end{array}$ & $P$ value \\
\hline January & 26.4 & 0.5 & 25.9 & -0.96 & 14 & NS & 26.2 & NS & 26.6 & NS \\
\hline February & 25.9 & 0.4 & 25.2 & -1.68 & 14 & NS & 26.0 & NS & 26.7 & NS \\
\hline March & 26.1 & 0.4 & 26.2 & 0.28 & 14 & NS & 26.4 & NS & 26.9 & 0.027 \\
\hline April & 26.7 & 0.4 & 27.6 & 2.38 & 14 & 0.016 & 27.3 & NS & 27.2 & NS \\
\hline May & 27.6 & 0.5 & 28.3 & 1.51 & 13 & NS & 28.0 & NS & 28.2 & NS \\
\hline June & 28.3 & 0.3 & 29.0 & 2.10 & 13 & 0.028 & 28.9 & 0.045 & 29.0 & 0.026 \\
\hline July & 28.5 & 0.4 & 29.2 & 1.73 & 13 & NS & 28.8 & NS & 29.0 & NS \\
\hline August & 28.8 & 0.4 & 29.6 & 1.99 & 12 & 0.035 & 28.8 & NS & 29.0 & NS \\
\hline September & 29.0 & 0.4 & 30.2 & 3.07 & 13 & 0.005 & 29.7 & NS & 29.5 & NS \\
\hline October & 28.9 & 0.3 & 29.3 & 1.24 & 13 & NS & 29.5 & NS & 29.3 & NS \\
\hline November & 28.2 & 0.3 & 28.6 & 1.19 & 13 & NS & 28.8 & NS & 28.3 & NS \\
\hline December & 27.2 & 0.4 & 27.1 & -0.11 & 13 & NS & 27.6 & NS & 27.1 & NS \\
\hline
\end{tabular}

Fig. 2 St. John seawater temperatures at reef depth in 2005-2007 compared with 1988-2004 data. Black line and error bars represent, respectively, the average, minimum, maximum of monthly average temperatures recorded at 3 reefs at St. John from 2005 to 2007 (Haulover, Newfound, Yawzi). Gray area shows range (minimummaximum) of monthly average temperatures recorded at the same 3 reefs from 1988 to 2004 . Number of sites with data loggers varied by month and year. Data loggers recorded temperature every $2 \mathrm{~h}$

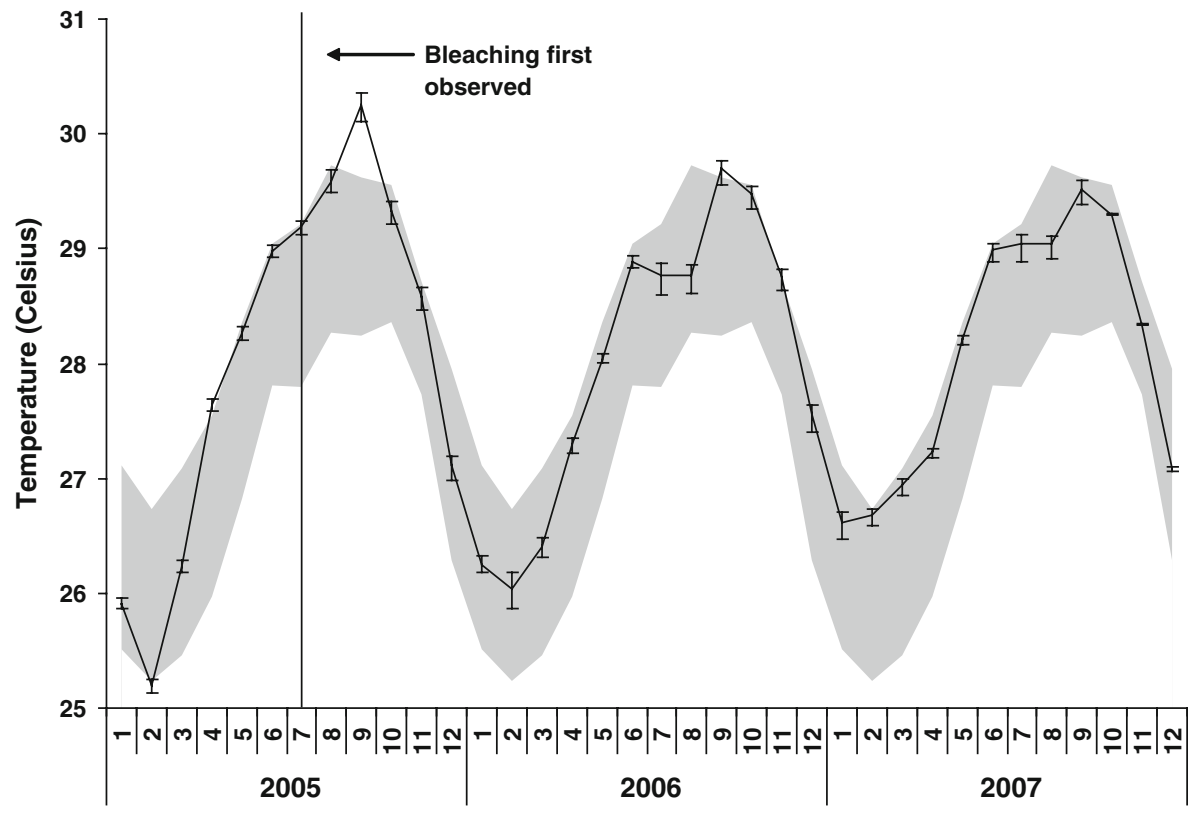

Twenty-one scleractinian species were quantified from the surveys at the onset of coral bleaching; with 16 species bleached including the 12 most-abundant ( $>0.5 \%$ cover). Within those species, maximum bleached cover by Montastraea annularis (complex) ranged from 98-99.5\% among study sites; Colpophyllia natans and Agaricia agaricites each ranged from 80 to $100 \%$; Porites porites, $75-100 \%$; and D. labyrinthiformis, $67-100 \%$. Three species however showed wider ranges of bleached cover: $M$. cavernosa (0-86\%), P. astreoides (62-84\%), and Siderastrea siderea (46-100\%). Interestingly, Madracis spp. were never observed as bleached (quantified under a random point) within the monitored transects during the study, but both
Madracis decactis and M. mirabilis/auretenra (Locke et al. 2007) were rare and found at only two sites. Bleaching was found throughout all depths (depth range $=3.7-18.9 \mathrm{~m}$ ), and depth was not a factor in the amount of coral cover bleached during maximum bleaching $(P=0.94)$.

\section{Disease}

Five known diseases/syndromes were observed throughout the study including black band disease, dark spot disease, white band disease (on Acroporid colonies), Caribbean yellow band disease, and white plague disease. However, $>95 \%$ of the disease-associated mortality showed signs 
consistent with white plague. Combining all sites, white plague was recorded on 19 coral species. White plague caused over 6,500 lesions and was responsible for over $86,000 \mathrm{~cm}^{2}$ of tissue loss. The genus Montastraea (excluding $M$. cavernosa) experienced the greatest mortality from white plague with $94.5 \%$ of the recorded disease-associated lesions. Colpophyllia natans, Diploria spp., Siderastrea siderea, and Porites spp. were affected by white plague as well, but at comparatively lower levels. Dark spot disease, black band, and white band diseases represented only $1.1,0.4$ and $0.4 \%$ of the total number of lesions, respectively. Caribbean yellow band disease was extremely rare. White plague and black band diseases were found within each study site, but only white plague was found during each sample period. Since over $95 \%$ of all recorded lesions were consistent with signs associated with white plague, disease, as discussed in the rest of this paper, will refer only to the loss of coral from signs similar to white plague disease.

Disease monitoring conducted at the reference sites (Haulover, Newfound, and South Fore Reefs) from January to March 2005 revealed an average of 0.5 disease-induced lesions per transect and $23.7 \mathrm{~cm}^{2}$ of tissue loss per transect before the onset of bleaching. When peak bleaching at the reference sites occurred (October-November 2005) the average number of lesions per transect increased to 3.3, and the average area of disease-induced mortality increased to $42.2 \mathrm{~cm}^{2}$ per transect. 'Peak' disease activity (defined as the greatest amount of disease-induced lesions and associated area of mortality: March-April 2006) at the three reference sites reached an average of 29.6 lesions and $298.7 \mathrm{~cm}^{2}$ of tissue loss per transect, representing a 51-fold increase in the number of lesions and 13-fold increase in the amount of area lost from disease when compared with initial surveys before bleaching occurred. Disease activity at Tektite Reef (see Fig. 3), not sampled before bleaching began, peaked earlier (November 2005) and higher (4.3 lesions per transect and $465.0 \mathrm{~cm}^{2}$ of tissue loss from disease per transect) than the reference sites, with 104-fold more lesions and 55-fold more disease-induced tissue loss than initial surveys at the reference sites.

The greatest amount of disease-induced mortality occurred within several months after the highest percent of bleached coral cover was observed except for Tektite Reef, where disease mortality and bleaching severity peaked simultaneously. Maximum disease-induced mortality did not occur at the same time for each site (see Fig. 4); however, most of the mortality was documented during the winter months, when water temperatures were similar to historical averages and re-coloration of corals had begun (Fig. 3). An average of $68.8 \%$ of all lesions and $65.6 \%$ of the disease-induced mortality occurred within 6 months after bleaching was first observed.
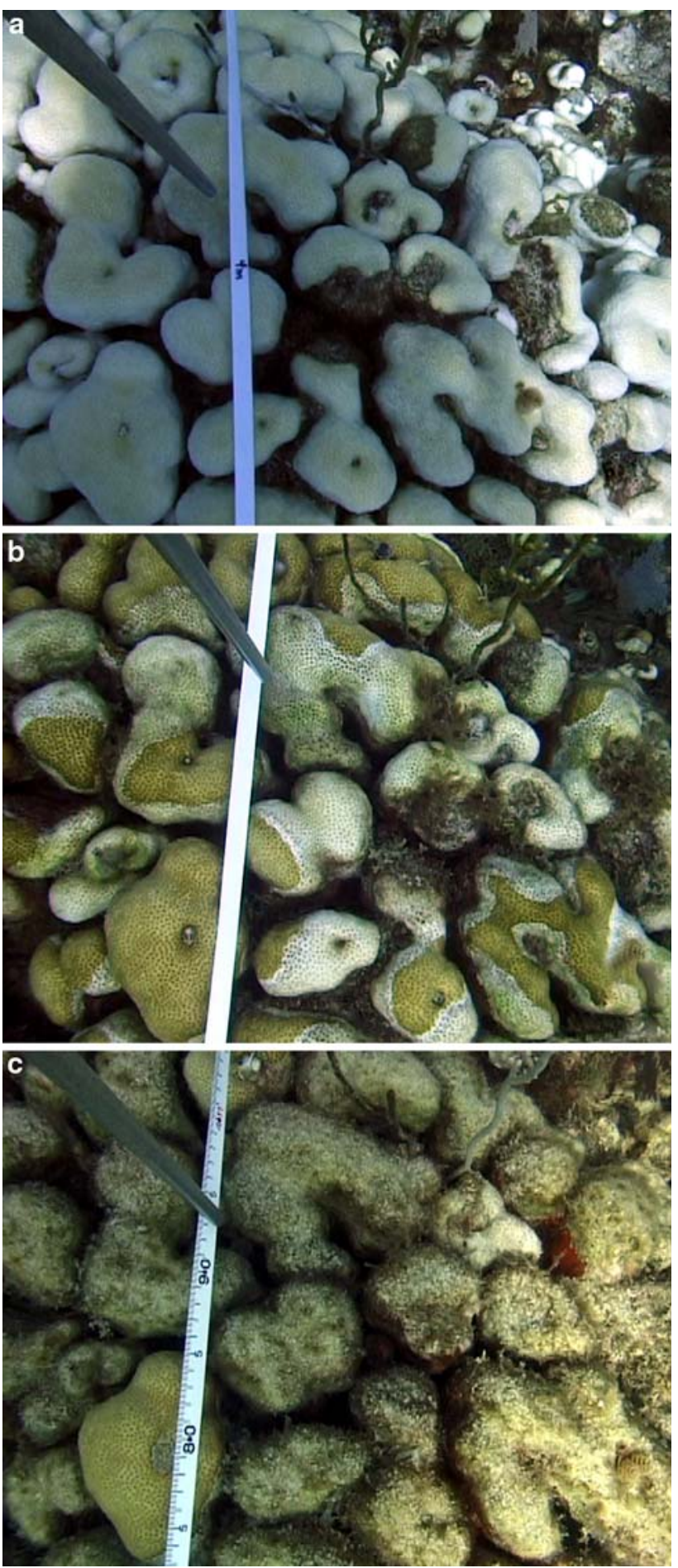

Fig. 3 Time series of identical video captures at Tektite Reef showing a bleached Montastraea annularis, September 2005, b $M$. annularis re-coloring and heavily affected by coral disease, November 2005, c near-total mortality of $M$. annularis with surviving portion still pale, January 2006

Disease activity at all sites remained elevated through July 2006 with two reference sites, Newfound Reef and Haulover Reef, still having 10 times more lesions and 
twice as much area of tissue loss from disease when compared with initial surveys. Continued monitoring of the disease in 2007 revealed the number of disease-induced lesions was similar to pre-bleaching values for two reference sites, Newfound and South Fore Reef. Haulover remained the only site that still showed a greater number of disease-induced lesions than pre-bleaching levels; however, the area of disease-associated mortality was similar to the initial surveys for all three sites. White plague was still the dominant disease representing $99.3 \%$ of the lesions, and $94.3 \%$ of the area of tissue loss from disease in 2007. Black band and white band were the only other two diseases recorded in 2007, but at comparatively low levels. Montastraea annularis (complex) was again the most significantly affected with $92 \%$ of the lesions and $86 \%$ of the area of tissue loss from disease occurring on this species group.

Annual comparisons between disease-induced lesions and temperature showed no correlation between the two variables in 2005 and 2007. However, in January through March 2006, the coolest period of that year, the number of lesions increased revealing a significant, negative association $\left(r_{\mathrm{s}}=-0.707, N=29, P=0.004\right)$. There were no associations between the area of disease-induced mortality and temperature during any year.

\section{Coral cover}

Significant coral cover loss occurred at all sites (Table 2) from before bleaching to the last sampling (October 2007, Mennebeck Reef). Average coral cover loss among sites was $51.5 \%$ (range: 42.4-61.8\%) within a year of the bleaching event (Fig. 4). Before bleaching in 2005, the mean coral cover among sites was $21.4 \%$ with three sites having more than $20 \%$ coral cover. Through sampling in 2006, mean coral cover among the sites dropped to $10.3 \%$ with no site having over $20 \%$ coral cover. Declines in mean coral cover continued at all sites between July 2006 through 2007; however, only one site (South Fore Reef) showed a statistically significant change, decreasing from

Table 2 Results of repeated measures contrast analysis, assuming a first-order auto-regressive covariance structure (SAS 9.2), contrast pre- versus post-event coral cover

\begin{tabular}{lcccccc}
\hline Site & \multicolumn{3}{l}{ Percent coral cover } & & $F$ & $P$ value \\
\cline { 2 - 5 } & Initial & SE & Post & SE & & \\
\hline Haulover Reef & 22.5 & 2.6 & 10.3 & 1.6 & 91.41 & 0.0001 \\
Newfound Reef & 13.3 & 1.6 & 6 & 0.8 & 247.66 & 0.0001 \\
Mennebeck Reef & 26.7 & 3.8 & 9.3 & 1.3 & 104.52 & 0.0001 \\
Tektite Reef & 24.7 & 2.5 & 11.6 & 1.5 & 115.34 & 0.0001 \\
S. Fore Reef & 19.8 & 1.6 & 4.1 & 0.4 & 190.97 & 0.0001 \\
\hline
\end{tabular}

$11.6 \%$ (March 2006) to $4.1 \%$ (February 2007). This demonstrates that losses continued even after March 2006. South Fore Reef had the largest cumulative site loss during the study with a $79.3 \%$ decline. Two years after the bleaching event, the mean loss in coral cover across all sites reached $61.1 \%$.

The number of disease-lesions showed no correlation with the percent coral cover $\left(r_{\mathrm{s}}=-0.065, N=29\right.$, $P=0.734)$, and there was no association between coral cover and area of disease-induced mortality over the entire sampling period $\left(r_{\mathrm{s}}=0.174, N=29, P=0.368\right)$.

\section{Species effects}

Montastraea annularis (complex), Colpophyllia natans, and Agaricia agaricites showed significant decreases in coral cover across the five sites (Table 3). Diploria labyrinthiformis, M. cavernosa, $P$. astreoides, and Siderastrea siderea did not show statistically significant decreases in cover across the five sites (statistical power to detect changes of $<50 \%$ relative cover for low-cover species was low).

Species-specific changes in coral cover affected the relative abundance of coral species on the reef. $M$. annularis (complex) remains the dominant coral species within these reefs; however, the relative abundance of this species group declined from an initial average of 79.2 to $58.6 \%$ of live coral cover (Fig. 5). C. natans also decreased in relative abundance from $1.3 \%$ prior to the onset of bleaching to $0.9 \%$ in 2006 (Fig. 5) likely from high levels of diseaseinduced mortality. On the other hand, A. agaricites declined primarily from bleaching mortality, as $93 \%$ of $A$. agaricites (cover) bleached but were rarely seen with disease. M. cavernosa, S. siderea, and Porites spp. bleached less than M. annularis (complex), C. natans, and Agariciids. They were less affected by disease than $M$. annularis (complex) and increased in relative abundance.

\section{Discussion}

While coral bleaching and coral disease are individually considerable threats to coral reefs, this study demonstrated the combination of the two can have catastrophic effects on living coral over a large spatial scale. The severity of disease in combination with region-wide bleaching resulted in the greatest total coral loss, affecting several species, ever documented within the Caribbean basin. These study sites represent 25 acres (10 hectares) of some of the most complex, diverse, and species-rich coral reefs in the USVI. Four of the reefs are located in long-established (multiple-decades) marine protected areas (MPAs). The ecological importance of 
Fig. 4 Mean coral cover (dark grey bars), overlaid with bleached coral cover levels (light grey and white bars) with standard error, and average area of disease-induced lesions (diamonds) with standard error from five study sites prior to the 2005 Caribbean coral-bleaching event to final monitoring in 2007. Notice Tektite has a different scale on the second $y$-axis. (Where error bars are not visible, they are within the data point.)
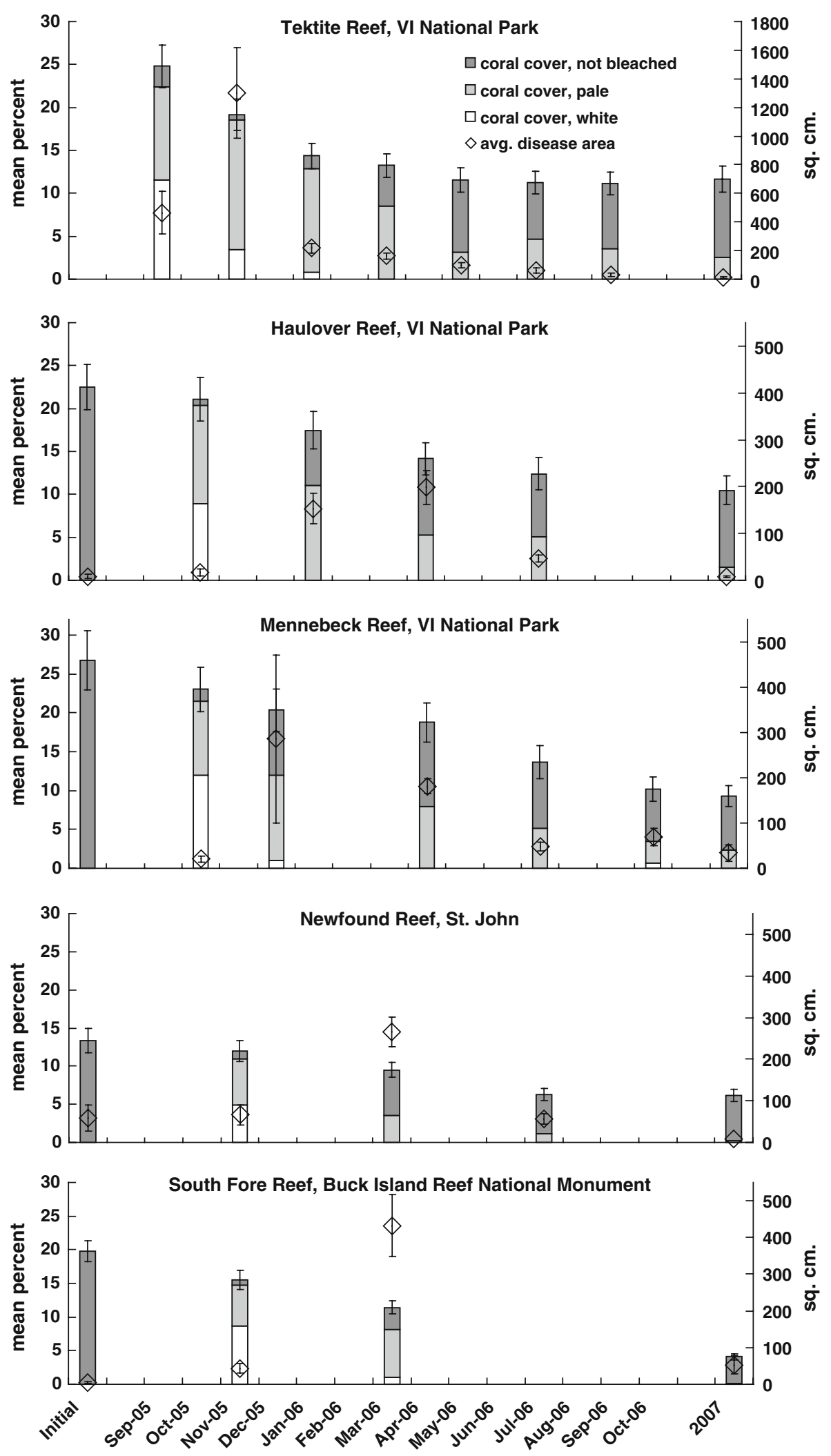

these reefs as sources of coral larvae, and as structure and habitat for fish communities and infaunal invertebrates, extend well beyond the reef boundaries.
Furthermore, tremendous losses in coral cover from 2005 to 2006 were not limited to these study sites. Annual monitoring (using the same techniques, although not at the 
Table 3 Results of $t$-test comparing pre- versus post-bleaching absolute percent cover of selected scleractinian species (NS: $P>0.05$ )

\begin{tabular}{|c|c|c|c|c|c|c|c|}
\hline \multirow[t]{2}{*}{ Species } & \multicolumn{4}{|c|}{ Mean percent cover } & \multirow[t]{2}{*}{$t$-value } & \multirow[t]{2}{*}{$d f$} & \multirow[t]{2}{*}{$P$ value } \\
\hline & Pre-bleaching & SE & Post-bleaching & SE & & & \\
\hline Montastraea annularis (complex) & 17.51 & 2.49 & 5.42 & 1.23 & 16.47 & 4 & $<0.001$ \\
\hline Colpophyllia natans & 0.33 & 0.09 & 0.11 & 0.05 & 4.76 & 4 & 0.009 \\
\hline Agaricia agaricites & 0.38 & 0.03 & 0.06 & 0.03 & 9.56 & 4 & $<0.001$ \\
\hline Diploria labyrinthiformis & 0.18 & 0.07 & 0.10 & 0.04 & 2.16 & 4 & NS \\
\hline M. cavernosa & 0.27 & 0.09 & 0.21 & 0.10 & 1.44 & 4 & NS \\
\hline
\end{tabular}

Fig. 5 Relative abundance of major coral taxa from five monitored sites in the US Virgin Islands prior to 2005 coralbleaching through 2007. Por spp $=$ Porites porites and Porites astreoides,

$\mathrm{MC}=$ Montastraea cavernosa,

$\mathrm{CN}=$ Colpophyllia natans, $\mathrm{Ag}$

spp $=$ Agaricia spp. are

displayed on left $Y$-axis.

MACX $=M$. annularis,

M. faveolata, M. franksi and undetermined Montastraea spp., are displayed on right $Y$-axis

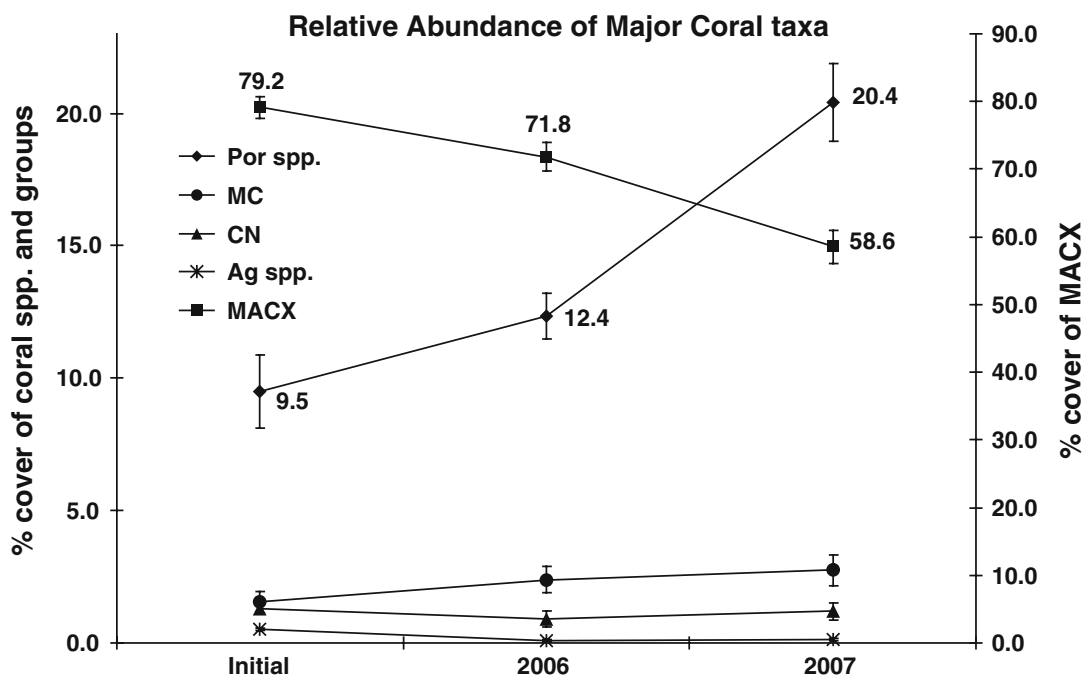

peak of bleaching or episodically thereafter) from two other USVI sites with lower initial coral cover (Yawzi Reef with $8.5 \%$ in St. John and Western Spur and Groove with $5.1 \%$ at Buck Island; Rogers et al. 2008) also showed dramatic coral cover losses of 48.1 and $41.5 \%$, respectively. Other surveys within territorial waters of the USVI also showed a decline of $40 \%$ coral cover likely from a white-plague-like syndrome (Woody et al. 2008). Similarly, Puerto Rico, approximately $100 \mathrm{~km}$ west of the USVI experienced record-breaking seawater temperatures that produced historically severe bleaching eventually followed by massive outbreaks of white plague and Caribbean yellow band disease. Losses in coral cover ranged from 20 to 97\% (Ballantine et al. 2008). The Natural Reserve of Culebra (50 km west of USVI) reported an epizootic of white plague post-bleaching with a resulting $67 \%$ decline in coral cover (Ballantine et al. 2008). The British Virgin Islands (BVI), approximately $35 \mathrm{~km}$ east of the US Virgin Islands, experienced similar conditions of elevated water temperatures with extensive coral bleaching followed by coral mortality from white plague (Bouchon et al. 2008). While coral bleaching was ubiquitous throughout the Caribbean in 2005, coral mortality was the highest from the USVI, Puerto Rico, and the BVI where coral disease epizootics followed the bleaching. This emphasizes the importance of frequency of monitoring (e.g., Miller et al. 2003, Borger and Steiner 2005), as with typical annual monitoring, the mortality from the epizootic would have been missed and probably attributed to bleaching.

The relationship among high-water temperatures, bleaching, and coral disease is poorly understood for scleractinian corals. Although it seems logical to think that high sea water temperatures stress corals and make them more susceptible to disease, the evidence is still rather limited. Some of the references that are cited to support this involve studies that: (1) have a small sample size (e.g., number of coral colonies-Kuta and Richardson 2002, Muller et al. 2008), (2) involve sampling over only a portion of the year, mostly in summer (Santavy et al. 2001), or (3) pertain to only a few diseases (usually black band disease in the Caribbean). Exceptions include Selig et al. (2006) and Bruno et al. (2007), both based on data from a 6 year study in the Great Barrier Reef. These studies show a correlation between "white syndrome" and high temperature but only in the presence of high coral cover $(>50 \%)$. Coral cover this high $(>50 \%)$ is extremely rare in the Caribbean. This study demonstrates that coral disease mortality can occur on reefs with "relatively" high or low coral cover as initial mean coral cover was $21.4 \%$ and decreased to $8.3 \%$ post-episode. 
Prior to the 2005 Caribbean coral-bleaching event, long term monitoring around St. John and Buck Island had shown decreasing coral cover due to hurricanes (e.g., Hubbard et al. 1991; Rogers et al. 1997), anchor damage (Rogers and Garrison 2001), disease (Miller et al. 2003), and overfishing (Rogers et al. 2008). However, documented coral cover losses were of smaller magnitude (e.g., from 20 to $13 \%$ at Yawzi Reef due to Hurricane Hugo, Rogers et al. 1997) and very localized. Recent monitoring (post-2000, but prior to 2005 bleaching) at the study reefs showed two sites within VINP with significant increases in coral cover suggesting that while MPAs are not a panacea for coral reefs (see Coelho and Manfrino 2007), a synergy of ecology and management could facilitate positive coral growth. The severity and duration of the 2005 coralbleaching event and subsequent disease outbreak superseded management and political boundaries affecting reefs within and outside national parks and eliminated any prebleaching gains in coral cover. During this study, coral cover declined on 99 of the 100 transects sampled (the only exception being one transect at Mennebeck Reef that went from 3.4 to $3.9 \%$ coral cover).

The direct cause of most coral mortality during and after the 2005 bleaching was disease that had signs consistent with white plague. This disease has been documented since the 1970s (Dustan 1977) and was first observed around the island of St. John in 1997 (Miller et al. 2003). Whiteplague-like signs have been observed in 41 different species of hard coral (Weil et al. 2006), including many major reef-building species. The causative agent of white plague type II has been identified as the alphaproteobacterium, Aurantimonas coralicida; however, this has fulfilled Koch's postulates on isolates from Dichocoenia stokesi only (Denner et al. 2003). In a separate study, a smaller section of Tektite Reef was monitored nearly monthly (88 months) for 8 years (December 1997-December 2005). During that time, mortality from white plague was observed each month and had no correlation with water temperatures (1997-2001, see Miller et al. 2003). Furthermore, a large outbreak of plague occurred in December 1998, 3 months after major bleaching occurred on that same reef (Miller et al. 2003). Significant mortality from coral disease, primarily consistent with white plague, was documented prior to 2005; however, this mortality was locally contained (i.e., within Haulover, Mennebeck, and Tektite Reefs, but not simultaneously). The disease outbreak that followed the 2005 Caribbean coral-bleaching event occurred on every reef monitored, both on St. John and BIRNM, $60 \mathrm{~km}$ south and resulted in the fastest decline in coral cover (of multiple species), from any cause, ever documented in the Virgin Islands.

This event struck hardest at the dominant reef-building coral M. annularis (complex) that initially comprised
$79.2 \%$ of the coral cover at the study sites. Cover of these slow-growing, broadcast spawning, and seldom-recruiting corals decreased $51 \%$ from its pre-bleaching initial cover. The losses of the $M$. annularis group, coupled with significant declines by other massive corals (e.g., C. natans), have resulted in a restructuring of the surviving coral community. $M$. annularis (complex) remains dominant but comprises only $58.6 \%$ of the corals, while the relative abundance of the brooding Porites spp. has increased from 9.8 to $20.4 \%$. Edmunds and Elahi (2007) reported a $72 \%$ decline in $M$. annularis on three $10 \mathrm{~m}$ transects at Yawzi Reef (500 m west of Tektite Reef) from 1988 to 1999, primarily from hurricanes, with bleaching having little effect (Edmunds 2002). They reported no disease on these transects during that time. Their model suggested an extirpation of $M$. annularis at their transects within 50 years; our study indicated that elimination of this species could occur over a large region in well under 50 years.

Interestingly, peak coral mortality did not coincide with peak bleaching activity and was rarely a direct result of bleaching. Most of the mortality occurred after water temperatures had returned to normal, and corals had regained some color. In fact, in 2006 there was a negative correlation between water temperature and number of disease-induced lesions $\left(r_{\mathrm{s}}=-0.707, P=0.004\right)$. This association, however, was not observed during any other year of monitoring, only in 2006 after severe coral bleaching occurred. Winter water temperatures in the Caribbean have shown an increasing trend over the last decade with warmer minimums observed (see Ballantine et al. 2008; Fig. 9.7 for La Paguera, Puerto Rico). Warmer winter temperatures may reduce the mortality rates of coral pathogens and increase the amount of coral disease (Bruno et al. 2007). The winter of 2006 was warmer than previous years, however, the winter in 2007 was even warmer. Disease did not increase following the warm 2007 winter, as it did in 2006 after anomalously high-water temperatures in summer/fall of 2005. Therefore, although warmer winter temperatures may play a role in coral disease activity, the peak in coral disease in the winter of 2006 was likely linked to the bleaching that preceded it. An alternative hypothesis is that the peak in disease activity during winter months of 2006 was a result of compromised corals. By monitoring throughout the 2005 episode in the USVI, Muller et al. (2008) showed that the size of disease-induced lesions on Acropora palmata increased as temperature increased, but only for bleached colonies. Lesion size on unbleached colonies of $A$. palmata remained the same when temperatures were high suggesting host-susceptibility, rather than temperature, influenced disease severity. The corals in the present study, having lost their symbiotic algae, were stressed for months possibly making them more susceptible to disease. The identified causative agent 
of white plague, A. coralicida, has a reported optimal growth from 30 to $35^{\circ} \mathrm{C}$ (Remily and Richardson 2006). The fact that disease peaked when temperatures were much lower than the optimal growth temperature of the pathogen suggests host susceptibility, rather than pathogen proliferation, was the driving force behind disease activity on scleractinian corals of the USVI in 2005-2006.

The present study suggests that most coral species in the Caribbean can recover from massive bleaching events and begin to do so soon after water temperatures return to normal; however, corals recovering from bleaching are likely to be more susceptible to diseases for several months. The predicted increases in water temperatures from global climate change will enhance the likelihood of coral bleaching, creating a population of potentially disease-susceptible individuals. Future monitoring of coralbleaching events should anticipate a subsequent coral disease outbreak from an increasingly stressful environment.

Acknowledgments The authors wish to thank the resource managers and superintendents at Virgin Islands National Park and Buck Island Reef National Monument, especially Rafe Boulon, and Zandy Hillis-Starr. Additional support was provided by Andy Davis, Andy Goldstein, Philip Gravinese, Ian Lundgren, Christy McManus, Judd Patterson, Dave Sapio, and Tony Spitzack. This work was funded by the National Park Service, US Geological Survey and the NOAA Coral Reef Ecosystem Studies program.

Open Access This article is distributed under the terms of the Creative Commons Attribution Noncommercial License which permits any noncommercial use, distribution, and reproduction in any medium, provided the original author(s) and source are credited.

\section{References}

Ainsworth TD, Fine M, Roff G, Hoegh-Guldberg O (2008) Bacteria are not the primary cause of bleaching in the Mediterranean coral Oculina patagonica. The International Society of Microbial Ecology Journal 2:67-73

Aronson RB, Precht WF, Toscano MA, Koltes KH (2002) The 1998 bleaching event and its aftermath on a coral reef in Belize. Mar Biol 141:435-447

Ballantine DL, Appeldoorn RS, Yoshioka P, Weil E, Armstrong R, Garcia JR, Otero E, Pagan F, Sherman C, Hernandez-Delgado EA, Bruckner A, Lilyestrom C (2008) Biology and ecology of Puerto Rican coral reefs. In: Riegl MB, Dodge RE (eds) Coral reefs of the USA. Springer, Dortrecht, pp 375-406

Ben-Haim Y, Rosenberg E (2002) A novel Vibrio sp. pathogen of the coral Pocillopora damicornis. Mar Biol 141:47-55

Borger JL, Steiner SCC (2005) The spatial and temporal dynamics of coral diseases in Dominica, West Indes. Bull Mar Sci 77(1):137154

Bouchon C, Portillo P, Bouchon-Navaro Y, Max L, Hoetjes P, Brathwaite A, Roach R, Oxenford H, O'Farrell S, Day O (2008) Status of coral reefs of the Lesser Antilles after the 2005 coral bleaching event. In: Wilkinson C, Souter D (eds) Status of Caribbean coral reefs after bleaching and hurricanes in 2005. Global Coral Reef Monitoring Network c/o Reef and Rainforest Research Centre, Townsville, pp 68-72
Brown BE (1997) Coral bleaching: causes and consequences. Coral Reefs 16:129-138

Bruno JF, Selig ER, Casey KS, Page CA, Willis BL, Harvell CD, Sweatman H, Melendy AM (2007) Thermal stress and coral cover as drivers of coral disease outbreaks. PLoS Biol 5(5):124125. doi:10.13471/journal.pbio.0050124

Coelho VR, Manfrino C (2007) Coral community decline at a remote Caribbean island: Marine no-take reserves are not enough. Aquat Conserv 17:666-685

Denner EBM, Smith GW, Busse H-J, Schumann P, Nartz T, Polson SW, Lubitz W, Richardson LL (2003) Aurantimonas coralicida gen. nov., sp. nov., the causative agent of white plague type II on Caribbean scleractinian corals. Int $\mathrm{J}$ Syst Evol Microbiol 53:1115-1122

Dustan P (1977) Vitality of reef coral populations off Key Largo, Florida: recruitment and mortality. Environ Geol 2:51-58

Edmunds PJ (2002) Long-term dynamics of coral reefs in St. John US Virgin Islands. Coral Reefs 21:357-367

Edmunds PJ, Elahi R (2007) The demographics of a 15-year decline in cover of the Caribbean reef coral Montastraea annularis. Ecol Monogr 77:3-18

Edmunds PJ, Gates RD, Gleason DF (2003) The tissue composition of Montastraea franksi during a natural bleaching event in the Florida Keys. Coral Reefs 22:54-62

Federal Register (2006) Endangered and threatened species: final listing determination for Elkhorn Coral and Staghorn Coral, vol 71, no 89, pp 26852-26861

Goreau T, McClanahan T, Hayes R, Strong A (2000) Conservation of coral reefs after the 1998 global bleaching event. Conserv Biol $1: 5-15$

Harvell D, Kim K, Burkholder J, Quirolo C, Weir J, Smith G (2001) Coral bleaching and disease: contributors to 1998 mass mortality in Briareum asbestinum (Octocorallia, Gorgonacea). Hydrobiologia 460:97-104

Harvell D, Aronson R, Baron N, Connell J, Dobson A, Ellner S, Gerber L, Kim K, Kuris A, McCallum H, Lafferty K, McKay B, Porter J, Pascual M, Smith G, Sutherland K, Ward J (2004) The rising tide of ocean diseases: unsolved problems and research priorities. Front Ecol Environ 2:375-382

Hoegh-Guldberg O (1999) Climate change, coral bleaching and the future of the world's coral reefs. Mar Freshw Res 50:839-866

Hubbard DK, Parsons KM, Bythell JC, Walker ND (1991) The effects of Hurricane Hugo on the reefs and associated environments of St. Croix, US Virgin Islands. J Coastal Res 8:22-48

Jones RJ, Bowyer J, Hough-Guldberg O, Blackall LL (2004) Dynamics of a temperature-related coral disease outbreak. Mar Ecol Prog Ser 281:63-77

Kuta KG, Richardson LL (2002) Ecological aspects of black band disease of corals: relationships between disease incidence and environmental factors. Coral Reefs 21:393-398

Lafferty KD, Porter JW, Ford SE (2004) Are diseases increasing in the ocean? Annual Review of Ecology Evolution and Systematics 35:31-54

Lesser MP, Bythell JC, Gates RD, Johnstone RW, Hoegh-Guldberg O (2007) Are infectious diseases really killing corals? Alternative interpretations of the experimental and ecological data. J Exp Mar Biol Ecol 346:36-44

Lewis JB (2004) Has random sampling been neglected in coral reef faunal surveys? Coral Reefs 23:192-194

List Editor (2001) Notification that new names and new combinations have appeared in volume 51, part 4 of the IJSEM. Int J Syst Evol Microbiol 51:1621-1623

Locke JM, Weil E, Coates KA (2007) A newly documented species of Madracis (Scleractinia: Pocilloporidae) from the Caribbean. Proc Biol Soc Wash 120:214-226 
Miller J, Rogers CS, Waara R (2003) Monitoring the coral disease, plague type II, on coral reefs in St. John, US Virgin Islands. Rev Biol Trop 51:47-55

Muller EM, Rogers CS, Spitzack AS, van Woesik R (2008) Bleaching increase likelihood of disease on Acropora palmata (Lamarck) in Hawksnest Bay, St. John, US Virgin Islands. Coral Reefs 27:191-195

Patterson KL, Porter JW, Ritchie KB, Polson SW, Mueller E, Peters EC, Santavy DL, Smith GW (2002) The etiology of white pox, a lethal disease of the Caribbean elkhorn coral, Acropora palmata. Proc Natl Acad Sci USA 99:8725-8730

Remily ER, Richardson L (2006) Ecological physiology of a coral pathogen and the coral reef environment. Microb Ecol 51:345352

Reshef L, Koren O, Loya Y, Zilber-Rosenberg I, Rosenberg E (2006) The coral probiotic hypothesis. Environ Microbiol 8:2068-2073

Rogers CS, Garrison VH (2001) Ten years after the crime: lasting effects of damage from a cruise ship anchor on a coral reef in St. John, US Virgin Islands. Bull Mar Sci 69:793-803

Rogers CS, Miller J (2001) Coral bleaching, hurricane damage, and benthic cover on coral reefs in St. John, US Virgin Islands: a comparison of surveys with the chain transect method and videography. Bull Mar Sci 69:459-470

Rogers CS, Garrison V, Grober-Dunsmore R (1997) A fishy story about hurricanes and herbivory: seven years of research on a reef in St John, U.S. Virgin Islands. Proc 8th Int Coral Reef Symp 1:555-560

Rogers CS, Miller J, Waara R (2002) Tracking changes on a reef in the US Virgin Islands with videography and SONAR: a new approach. Proc 9th Int Coral Reef Symp 2:1065-1071

Rogers CS, Miller J, Muller EM, Edmunds P, Nemeth RS, Beets JP, Friedlander AM, Smith TB, Boulon R, Jeffrey CFG, Menza C, Caldow C, Idrisi N, Kojis B, Monaco ME, Spitzack A, Gladfelter EH, Ogden JC, Hillis-Starr Z, Lundgren I, Schill WB, Kuffner IB, Richardson LL, Devine BE, Voss JD (2008) Ecology of coral reefs in the US Virgin Islands. In: Riegl BM, Dodge RE (eds) Coral reefs of the USA. Springer, Dortrecht, pp 303-373

Rosenberg E, Ben-Haim Y (2002) Microbial diseases of corals and global warming. Environ Microbiol 4:318-326
Rosenberg E, Loya Y (2004) Coral health and disease. SpringerVerlag, Berlin, p 488

Santavy DL, Mueller E, Peters EC, MacLaughlin L, Porter JW, Patterson KL, Campbell J (2001) Quantitative assessment of coral diseases in the Florida Keys: strategy and methodology. Hydrobiologia 46:39-52

Selig ER, Harvell CD, Bruno JF, Willis BL, Page CA, Casey KS, Sweatman H (2006) Analyzing the relationship between ocean temperature anomalies and coral disease outbreaks at broad spatial scales. In: Phinney JT, Hoegh-Guldberg O, Kleypas J, Skirving W, Strong A (eds) Coral reefs and climate change: science and management. American Geophysical Union, Washington, $\mathrm{p} 244$

Squires DF (1965) Neoplasia in a coral? Science 148:503-505

Weil E (2004) Coral reef diseases in the wider Caribbean. In: Rosenberg EH, Loya Y (eds) Coral health and disease. SpringerVerlag, Berlin, pp 35-68

Weil E, Smith G, Gil-Agudelo DL (2006) Status and progress in coral reef disease research. Dis Aquat Org 69:1-7

Whelan KRT, Miller J, Sanchez O, Patterson M (2007) Impact of the 2005 coral bleaching event on Porites porites and Colpophyllia natans at Tektite Reef, US Virgin Islands. Coral Reefs 26:689693

Wilkinson C, Souter D (2008) Status of Caribbean coral reefs after bleaching and hurricanes in 2005. Global coral reef monitoring network c/o Reef and Rainforest Research Centre, Townsville 148

Williams EH, Bunkley-Williams L (1990) The world-wide coral reef bleaching cycle and related sources of coral mortality. Atoll Res Bull 335:1-67

Woody K, Atkinson A, Clark R, Jeffrey C, Lundgren I, Miller J, Monaco M, Muller E, Patterson M, Rogers C, Smith T, Spitzack T, Waara R, Whelan K, Witcher B, Wright A (2008) Coral bleaching in the US Virgin Islands in 2005 and 2006. In: Wilkinson C, Souter D (eds) Status of Caribbean coral reefs after bleaching and hurricanes in 2005. Global Coral Reef Monitoring Network c/o Reef and Rainforest Research Centre, Townsville, pp 68-72 